\title{
Cooling the Heat - Traditional remedies for malaria and fever in Northern Peru
}

\author{
Rainer W. Bussmann and Ashley Glenn
}

\section{Research}

\begin{abstract}
Malaria continues to be a major health challenge worldwide especially due to the increasingly fast development of resistance of Plasmodium falciparum to the drugs currently in use.
\end{abstract}

A total of 17 plant species belonging to 17 genera and 13 families were documented and identified as anti-malarial herbal remedies in Northern Peru. Most species used were in Asteraceae, followed by Fabaceae and Solanaceae. The majority of anti-malarial herbal preparations were made from the leaves of plants, while the whole plant, flowers and stems were used less frequently. This suggests that the local healers count on a very well developed knowledge about the properties of different plant parts. In almost $70 \%$ of the cases fresh plant material was used to prepare remedies. Over half of all remedies were prepared as mixtures with multiple ingredients by boiling plant material either in water or in sugarcane spirit.

The information gained on frequently used traditional remedies against malaria might give some leads towards future targets for further analysis in order to develop new anti-malaria drugs. However, more detailed scientific studies are desperately needed to evaluate the efficacy and safety of the remedies employed traditionally.

\section{Resumen}

Malaria todavía continua como problema de salud mayor al nivel global, especialmente por la rapidez de desarrollo de resistencias en Plasmodium falciparum a los medicamentos en uso.

Un total de 17 especies de plantas medicinales de 17 géneros y 13 familias han sido documentadas e identificadas como plantas anti-malariales en el Norte de Perú. La mayoría de as especies pertenece a Asteraceae, Fabaceae y Solanaceae. La mayoría de las plantas prepara- ciones en contra de malaria fueron preparadas de las hojas de las plantas, mientras que la planta entera, flores y tallos fueron usados con menos frecuencia. Este indica que los curanderos locales tienen un conocimiento muy profundo de las propiedades de diferentes partes de las plantas. En casi $70 \%$ de los casos usaron material fresco para preparar los remedios. Casi la mitad de los remedios fueron preparados como mezcla con ingredientes múltiples en agua o aguardiente.

La información encontrado sobre remedies usados con frecuencia contra malaria pueda apoyar en encontrar nuevos posibilidades de análisis para el desarrollo de nuevos compuestos anti-malariales. Sin embargo, se necesita estudios mas detallados sobre la eficaz y la toxicidad de los remedies tradicionalmente usados.

\section{Introduction}

Malaria is still a major global public health problem in most tropical countries. It is thought that malaria is by far the most serious tropical disease causing one to two million deaths per year, and it plays a major role in the high

\section{Correspondence}

Rainer W. Bussmann, William L. Brown Center, Missouri Botanical Garden, P.O. Box 299, St. Louis, MO 63166-0299, U.S.A. rainer.bussmann@mobot.org

Ashley Glenn, William L. Brown Center, Missouri Botanical Garden, P.O. Box 299, St. Louis, MO 63166-0299, U.S.A.

Ethnobotany Research \& Applications 8:125-134 (2010)

Published: May 28, 2010 
mortality seen in infants and children (El Kamali \& El Kijalifa 1997, Milliken 1997). It is also responsible for miscarriages, premature deliveries, growth retardation, low birth weight and anemia (Connally et al. 1996, Geissler et al. 1998, Hay et al. 2003, Minakawa et al. 2002).

The World Health Organization (WHO) has estimated that about 2 billion people in over 100 countries are exposed to malaria, with 247 million cases in 2006 alone, and half of the world's population is potentially exposed to the disease (WHO 2009). The worsening global economic situation makes it difficult to expand modern health services, hence effective low-cost delivery medical system is urgently needed (El Kamali \& El Kijalifa 1996).

This is even more pressing because the use and misuse of over the counter anti-malaria remedies like chloroquine to prevent and treat falciparum malaria has led to widespread appearance of resistant parasites (Milliken 1997). This is complicated by the fact that global warming may lead to expansion of areas in which the ambient temperature and climatic conditions are suitable for plasmodium transmission. Climatic variability has been associated with some of the recent epidemics (Minawaka et al. 2002).

Northern Peru is believed to be the center of the Central Andean Health Axis (Camino 1992), and traditional medicinal practices in this region are still an important component of everyday life (Bussmann 2006b, Bussmann \& Sharon 2006, De Feo 1992, Joralemon \& Sharon 1993, Polia 1988, Sharon 1978, 1980, 1994, 2000, Sharon \& Bussmann 2006). Traditional Medicine is also gaining more and more respect by national governments and health providers. Peru's National Program in Complementary Medicine and the Pan American Health Organization recently compared Complementary Medicine to allopathic medicine in clinics and hospitals operating within the Peruvian Social Security System (EsSalud 2000). According to WHO (2002), the sustainable cultivation and harvesting of medicinal species is one of the most important challenges for the next few years.

The present study attempts to give an overview on medicinal plant species employed in traditional therapies in Northern Peru to treat malaria, and compare this use to the western scientific evidence regarding their efficacy.

\section{Materials and Methods}

\section{Plant Collections}

Plants in Peru were collected in the field, in markets, and at the homes of traditional healers (curanderos) in Northern Peru (Figure 1) in August-September 2001, July-August 2002, July-August 2003, June-August 2004, July-August 2005, July-August 2006, June-August 2007, JuneAugust 2008, March-April 2009 and June-August 2009.
A total of 116 informants (healers and market venders) in the Trujillo and Chiclayo area were interviewed using structured questionnaires. The informants were always provided with fresh plant material, either collected with them, by them, or available at their market stands. The questionnaires did not include any reference as to disease concepts, plant parts or preparations. In contrast, the participants were only asked simple questions along the lines "What is this plant used for, which part, which quantity, how is it prepared, are any other plants added to the mixture." All questions were asked in the same order. All informants were of Mestizo origin, and spoke only Spanish as their native language. The study covered the four existing medicinal plant markets of the region, and included all venders present. All interviews were conducted with the same set of participants. The specimens are registered under the collection series "RBU/PL," "ISA," "GER," "JULS," "EHCHL," "VFCHL," "TRUBH," and "TRUVANERICA," depending on the year of fieldwork and collection location. Surveys were conducted in Spanish by fluent speakers. Surveyors would approach healers, collectors and market vendors and explain the premise for the study, including the goal of conservation of medicinal plants in the area.

Vouchers of all specimens were deposited at the Herbario Truxillensis (HUT, Universidad Nacional de Trujillo), and Herbario Antenor Orrego (HAO, Universidad Privada Antenor Orrego Trujillo). In order to recognize Peru's rights under the Convention on Biological Diversity, most notably with regard to the conservation of genetic resources in the framework of a study treating medicinal plants, the identification of the plant material was conducted entirely in Peru. No plant material was exported in any form whatsoever.

\section{Nomenclature}

The nomenclature of plant families, genera, and species follows the Catalogue of the Flowering Plants and Gymnosperms of Peru (Brako \& Zarucchi 1993) and the Catalogue of Vascular Plants of Ecuador (Jørgensen \& León-Yanez 1999). The nomenclature was compared to the TROPICOS database. Species were identified using the available volumes of the Flora of Peru (McBride 19361981), as well as Jørgensen \& Ulloa Ulloa (1994), Pestalozzi (1998) and Ulloa Ulloa \& Jørgensen (1993), and the available volumes of the Flora of Ecuador (Sparre \& Harling 1978-2009), and reference material in the herbaria HUT, HAO, QCA, LOJA and QCNE.

\section{Results}

A total of 17 plant species belonging to 17 genera and 13 families were documented and identified as anti-malarial herbal remedies in Northern Peru. Most species used were in Asteraceae while most families only contributed 


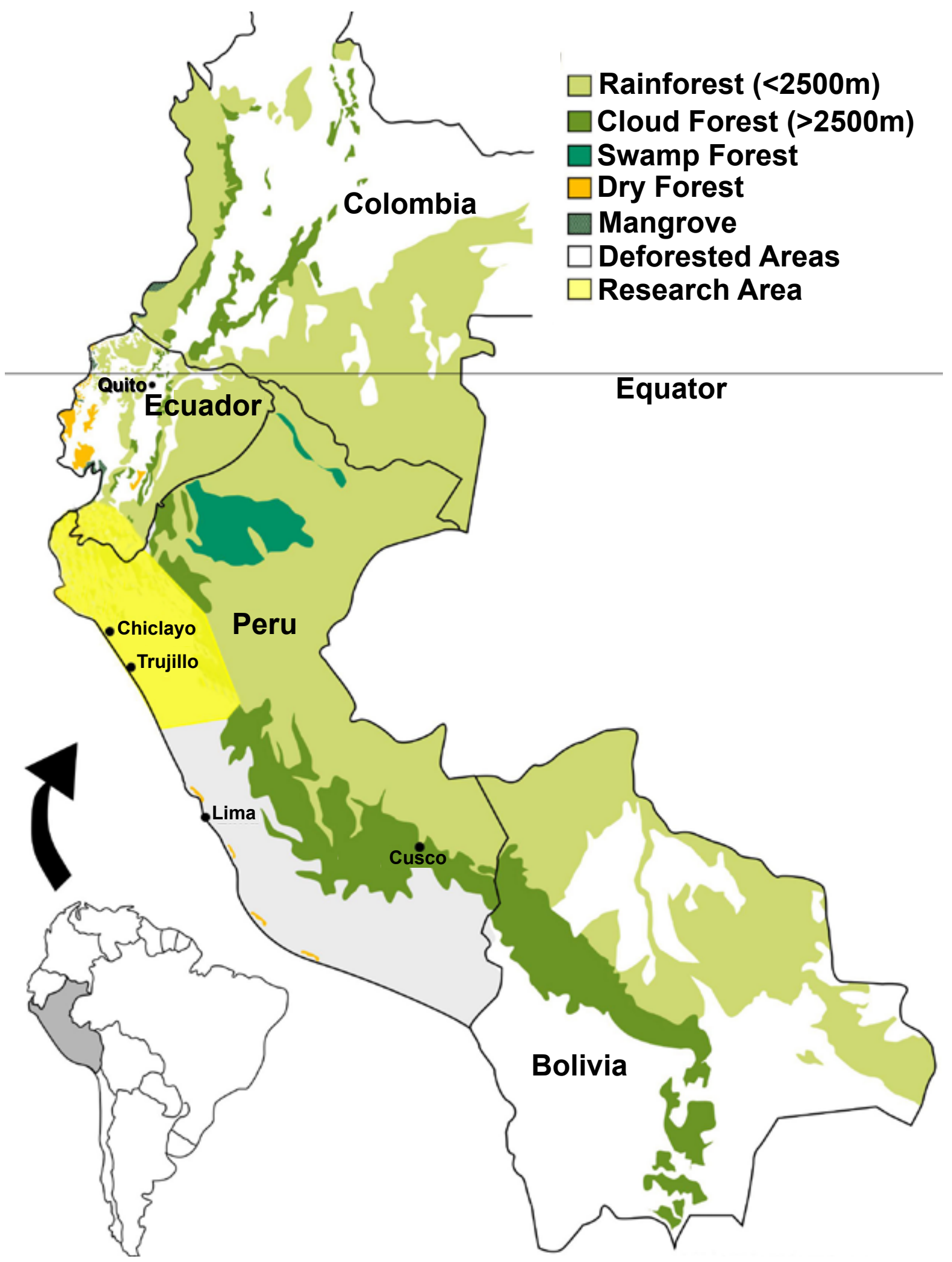

Figure 1. Research area in Northern Peru and adjoining environmental areas. 
one species (Table 1). A complete overview of all plants encountered, including data on use-recipes and preparation, is given in Appendix 1. The most important anti-malarial families are clearly over-represented in comparison to the overall medicinal flora, while some other medicinally important families (e.g., Lamiaceae, Euphorbiaceae, Poaceae, Apiaceae) are completely missing from the antimalarial portfolio (Table 2) (Bussmann \& Sharon 2006). In the context of the questionnaires healers and venders often referred to "Fever" when talking about malaria. Fever however included a variety of conditions, from fevers accompanying flu to fever as a result of malaria. Malaria was recognized as a parasitic infection, and treated accordingly, while other plant species were used to treat fever as a symptom, mainly focusing on lowering body temperature. The majority of anti-malarial herbal preparations were prepared from the leaves of plants $(38.46 \%)$, while other parts were used less frequently (Table 3). Leaves and stems were used more often for malaria treatments than would have been expected in comparison to the overall medicinal preparations found in the region, while seeds of plants were employed much less frequently and other plant parts not at all (Table 3, Bussmann \& Sharon 2006). This indicates that the local healers count on a very well developed knowledge about the properties of different plant parts. In almost $70 \%$ of the cases fresh plant material was used to prepare remedies, which differs little from the average herbal preparation mode in Northern Peru (fresh $69.6 \%$ : dry $30.4 \%$ ). Interestingly, only about $55 \%$ of the remedies were applied orally, while the remaining ones were applied topically. This is little different from the regional average of application. Over half of all remedies were prepared as mixtures of multiple ingredients by boiling plant material either in water or in sugarcane spirit.

Table 1. Plants used to treat malaria in Northern Peru.

\begin{tabular}{|c|c|c|c|}
\hline Family & Genera & Species & $\%$ \\
\hline Asteraceae & 3 & 3 & 17.66 \\
\hline Fabaceae & 2 & 2 & 11.77 \\
\hline Solanaceae & 2 & 2 & 11.77 \\
\hline Caprifoliaceae & 1 & 1 & 5.88 \\
\hline Clusiaceae & 1 & 1 & 5.88 \\
\hline Convolvulaceae & 1 & 1 & 5.88 \\
\hline Cyperaceae & 1 & 1 & 5.88 \\
\hline Gentianaceae & 1 & 1 & 5.88 \\
\hline Polygonaceae & 1 & 1 & 5.88 \\
\hline Ranunculaceae & 1 & 1 & 5.88 \\
\hline Salicaceae & 1 & 1 & 5.88 \\
\hline Tiliaceae & 1 & 1 & 5.88 \\
\hline Verbenaceae & 1 & 1 & 5.88 \\
\hline & & & 100 \\
\hline
\end{tabular}

Table 2. Comparison of the anti-malarials to the 10 most important plant families of the medicinal flora of Northern Peru (after Bussmann \& Sharon 2006).

\begin{tabular}{|l|c|c|}
\hline Family & $\begin{array}{c}\text { Medicinal } \\
\text { flora of North } \\
\text { Peru (\%) }\end{array}$ & $\begin{array}{c}\text { Malaria and } \\
\text { Fever (\%) }\end{array}$ \\
\hline Asteraceae & 13.64 & 17.66 \\
\hline Fabaceae & 6.82 & 11.77 \\
\hline Lamiaceae & 4.87 & 0 \\
\hline Solanaceae & 4.09 & 11.77 \\
\hline Euphorbiaceae & 2.33 & 0 \\
\hline Poaceae & 2.33 & 0 \\
\hline Apiaceae & 2.14 & 0 \\
\hline Lycopodiaceae & 1.95 & 0 \\
\hline Cucurbitaceae & 1.75 & 0 \\
\hline Rosaceae & 1.75 & 0 \\
\hline
\end{tabular}

Table 3. Plant parts used in anti-malarials in Northern Peru.

\begin{tabular}{|c|c|}
\hline Plant Part & $\%$ \\
\hline Leaves & 38.46 \\
\hline Whole plant & 26.92 \\
\hline Flowers & 15.38 \\
\hline Stems & 11.54 \\
\hline Seeds & 3.85 \\
\hline Fruit & 3.85 \\
\hline
\end{tabular}

\section{Discussion}

The very limited number of plants employed at the Peruvian coast to treat malaria and fevers might on a first glance surprise, if compared to studies from other regions of the country (e.g., Kvist et al. 2007, Roumy et al. 2007). However, malaria has always been of relatively minor importance in the coastal desert areas, and thus it is not surprising that few remedies are employed. There are indications that health practices are in the process of changing, and traditional healers start to treat a patient with prepared western remedies (e.g., aspirin, Lariam ${ }^{\circledR}$ (mefloquine hydrochloride), Malaraquin ${ }^{\circledR}$ (chloroquine phosphate) or primaquine) although plant preparations are still important (Bussmann \& Sharon 2006, Bussmann et al. 2007).

Little scientific evidence exists to prove the efficacy of the species employed as malaria remedies in Northern Peru. Only $41 \%$ of the plants found or their congeners have been studied at all for their medicinal properties. Sambucus spp. are known to be used against malaria in Turkey Everest \& Ozturk 2005) and Trinidad (Lans et al. 2001), and Stowers et al. (2002) showed anti-plasmodial activity in an extract of a species of the genus. Hypericum spp. are traditionally used in Turkey and Southern Peru to 


\section{Bussmann \& Glenn - Cooling the Heat - Traditional remedies for malaria and 129 fever in Northern Peru}

treat malaria (Bletter 2007, Everest \& Ozturk 2005), while various species of Ipomoea are used in Africa (Bussmann 2006a, Bussmann et al. 2006, Kayode 2006, Knols et al. 2002) and the Philippines (Lacuna-Richman 2006). The genus Salix is well known as a source of Acetylsalicylic acid, widely used as analgesic and antipyretic. A wide variety of Solanaceae, including species of the genera Cestrum and Solanum are widely used as mosquito repellents or as larvicidals (Chowdhury et al. 2008, Rajkumar \& Jebansesan 2005), or are traditionally used as malaria treatment (Bussmann 2006, Bussmann et al. 2006, Lans et al. 2001, Makundi et al. 2006, Nanjingi et al. 2008, Njoroge \& Bussmann 2006, Sajem \& Gosai 2006, Teklehayamont \& Giday 2007), while Verbena sp. is known as anti-malarial from Ethiopia (Teklehayamont \& Giday 2007).

\section{Conclusions}

Malaria continues to be a major health challenge worldwide especially due to the increasingly fast development of resistance of Plasmodium falciparum to the drugs currently in use. Many plant species are traditionally used for malaria treatment, and some have been investigated for their efficacy with positive results. An often-limiting factor to these investigations is lack of comprehensive ethnobotanical data to help choose plant candidates for potency/efficacy tests. Since the plant parts utilized in preparation of anti-malarial remedies are reported in this survey, it serves as an indication of species that may need further ecological assessment on their regeneration status.

The results of this study show that both indigenous and introduced species are used for malaria treatment and as mosquito repellents. The information gained on frequently used traditional remedies against malaria might give some leads for future targets for further analysis in order to develop new anti-malaria drugs. However, more detailed scientific studies are desperately needed to evaluate the efficacy and safety of the remedies employed traditionally.

\section{Acknowledgements}

The presented study was financed through MIRT/MHIRT (Minority Health Disparity International Research and Training) a grant from the National Institutes of Health (Fund: 54112B MHIRT Program, Grant: G0000613). Fieldwork for this project was supported through the assistance of a large number of MIRT/MHIRT students and volunteers. Thanks to all of them. None of the work would have been possible without the invaluable collaboration of our Peruvian colleagues, especially curanderas Julia Calderón, Isabel Chinguel, and Olinda Pintado, curanderos Germán Santisteban and Leoncio Carrión, and herbalists Manuel Bejarano, Elmer Cruz, and Iván Cruz. Thanks also go to Eric Rodriguez (Herbarium Truxillense, HUT) and Abundio Sagastegui, Segundo Leiva, and Ma- rio Zapata (Herbario Antenor Orrego, HAO) for the use of their facilities and their assistance in plant identification.

\section{Literature Cited}

Bletter, N. 2007. A quantitative synthesis of the medicinal ethnobotany of the Malinké of Mali and the Asháninka of Peru, with a new theoretical framework. Journal of Ethnobiology and Ethnomedicine 3:36.

Brako, L. \& J.L. Zarucchi. 1993. Editors of Catalogue of the Flowering Plants and Gymnosperms of Peru. Missouri Botanical Garden, St. Louis, Missouri.

Bussmann, R.W. 2006a. Ethnobotany of the Samburu of Mt. Nyiru, South Turkana, Kenya. Journal of Ethnobiology and Ethnomedicine 2:35.

Bussmann, R.W. 2006b. Manteniendo el balance de naturaleza y hombre, La diversidad florística andina y su importancia por la diversidad cultural - ejemplos del Norte de Perú y Sur de Ecuador. Arnaldoa 13(2):382-397.

Bussmann, R.W., G.G. Gilbreath, J. Solio, M. Lutura, R. Lutuluo, K. Kunguru, N. Wood \& S.G. Mathenge. 2006. Plant use of the Maasai of Sekenani Valley, Maasai Mara, Kenya. Journal of Ethnobiology and Ethnomedicine 2:22.

Bussmann, R.W. \& D. Sharon. 2006. Traditional plant use in Northern Peru, Tracking two thousand years of health culture. Journal of Ethnobiology and Ethnomedicine 2:47.

Bussmann, R.W., D. Sharon \& A. Lopez. 2007. Blending traditional and western medicine. Medicinal plant use amongst patients at Clinica Anticona in El Porvenir, Peru. Ethnobotany Research and Application 5:185-199.

Camino, L. 1992. Cerros, plantas y lagunas poderosas, la medicina al norte de Perú. Lluvia Editores, Lima.

Chowdhury, N., A. Ghosh \& G. Chandra. 2008. Mosquito larvicidal activities of Solanum villosum berry extract against the dengue vector Stegomyia aegypti. BMC Complementary and Alternative Medicine 8:10.

Connally, M.P.E., E. Fabiano, I.H. Patel, S.M. Kinyanjui, E.K. Mberu \& W.M. Watkins. 1996. Antimalarial activity in crude extracts of Malawian medicinal plants. Annals of Tropical Medicine and Parasitology 90:597-602.

De Feo, V. 1992. Medicinal and magical plants on northern Peruvian Andes. Fitoterapia 63:417-440.

El Kamali, H. \& K.E. El Kijalifa. 1997. Treatment of malaria through herbal drug in the central Sudan. Fitoterapia $6: 527-528$. 
EsSalud. 2000. Organización Panamericana de Salud. Estudio Costo-Efectividad: Programa Nacional de Medicina Complementaria. Seguro Social de EsSalud. EsSalud/ Organización Panamericana de Salud, Lima.

Everest, A. \& E. Ozturk. 2005. Focusing on the ethnobotanical uses of plants in Mersin and Adana provinces (Turkey). Journal of Ethnobiology and Ethnomedicine 1:6.

Geissler, P.W., D.L. Mwaniki, F. Thiong'o, K.F. Michaelsen \& H. Friis. 1998. Geophagy, iron status and anemia among primary school children in Western Kenya. Tropical Medicine and International Health 3(7):529-534.

Hay, S.I., E.C. Were, M. Renshaw, A.M. Noor, S.A. Ochola, I. Olusanmi, N. Alipui \& R.W. Snow. 2003. Forecasting, warning, and detection of malaria epidemics: A case study. Lancet 361(9370):1705-1706.

Joralemon, D. \& D. Sharon. 1993. Sorcery and Shamanism, Curanderos and Clients in Northern Peru. University of Utah Press, Salt Lake City.

Jørgensen, P.M. \& S. León-Yanez. 1999. Editors of Catalogue of the Vascular Plants of Ecuador. Monographs in Systematic Botany 75. Missouri Botanical Garden Press, St. Louis, Missouri.

Jørgensen, P.M. \& C. Ulloa Ulloa. 1994. Seed plants of the High Andes of Ecuador - a Checklist. Aarhus University (AAU) Reports 34:1-443.

Kayode, J. 2006. Conservation of indigenous medicinal botanicals in Ekiti State, Nigeria. Journal of the Zhejiang University of Science B. 7(9):713-718.

Knols, B.G.J., B.N. Njiru, E.M. Mathenge, W.R. Mukabana, J.C. Beier \& G.F. Killeen. 2002. MalariaSphere, A greenhouse-enclosed simulation of a natural Anopheles gambiae (Diptera, Culicidae) ecosystem in western Kenya. Malaria Journal 1:19.

Kvist, L.P., S.B. Christensen, H.B. Rasmussen, K. Mejia \& A. Gonzalez. 2006. Identification and evaluation of Peruvian plants to treat malaria and leishmaniasis. Journal of Ethnopharmacology 106:390-402.

Lacuna-Richman, C. 2006. The use of non-wood forest products by migrants in a new settlement, experiences of a Visayan community in Palawan, Philippines. Journal of Ethnobiology and Ethnomedicine 2:36.

Lans, C., T. Harper, K. Georges \& E. Bridgewater. 2001. Medicinal and ethnoveterinary remedies of hunters in Trinidad. BMC Complementary and Alternative Medicine 1:10.
Makundi, E.A., H.M. Malebo, P. Mhame, A.Y. Kitua \& M. Warsame. 2006. Role of traditional healers in the management of severe malaria among children below five years of age, the case of Kilosa and Handeni Districts, Tanzania. Malaria Journal 5:58.

McBride, J.F. 1936-1981. Editor of Flora of Peru. Fieldiana, Botany. Field Museum of Natural History, Chicago.

Milliken, W. 1997. Traditional anti-malarial medicine in Roraim, Brazil. Economic Botany 51(3):212-237.

Minakawa, N., G. Sonye, M. Mogi, A. Githeko \& G.Y. Yan. 2002. The effects of climatic factors on the distribution and abundance of malaria vectors in Kenya. Journal of Medical Entomology 39(6):833-841.

Nanyingi, M.O., J.M. Mbaria, A.L. Lanyasunya, C.G. Wagate, K.B. Koros, H.F. Kaburia, R.W. Munenge \& W.O. Ogara. 2008. Ethnopharmacological survey of Samburu district, Kenya. Journal of Ethnobiology and Ethnomedicine 4:14.

Njoroge, G.N. \& R.W. Bussmann. 2006. Diversity and utilization of antimalarial ethnophytotherapeutic remedies among the Kikuyus (Central Kenya). Journal of Ethnobiology and Ethnomedicine 2:8.

Pestalozzi, H.U. 1998. Flora ilustrada altoandina. Herbario Nacional de Bolivia and Herbario Forestal Nacional Martín Cardenas, Cochabamba.

Polia, M. 1988. Las Lagunas de los Encantos - Medicina Tradicional Andina en el Peru septentrional. Central Peruana de Servicios, Lima.

Rajkumar, S. \& A. Jebanesan. 2005. Oviposition deterrent and skin repellent activities of Solanum trilobatum leaf extract against the malarial vector Anopheles stephensi. Journal of Insect Science 5:15.

Roumy, V., G. Garcia-Pizango, A.-L. Gutierrez-Choquevilca, L. Ruiz, V. Jullian, P. Winterton, N. Fabre, C. Moulis \& A. Valentin. 2007. Amazonian plants from Peru used by Quechua and Mestizo to treat malaria with evaluation of their activity. Journal of Ethnopharmaciology 112:482489 .

Sajem, A.L. \& K. Gosai. 2006. Traditional use of medicinal plants by the Jaintia tribes in North Cachar Hills district of Assam, northeast India. Journal of Ethnobiology and Ethnomedicine 2:33.

Sharon, D. 1978. Wizard of the Four Winds, A Shaman's Story. Free Press, New York.

Sharon, D. 1980. El Chamán de los Cuatro Vientos. Siglo veintiuno editores, México, District Federal. 


\section{Bussmann \& Glenn - Cooling the Heat - Traditional remedies for malaria and 131 fever in Northern Peru}

Sharon, D. 1994. Tuno y sus colegas, notas comparativas. Pp. 128-147 in En el Nombre del Señor, Shamanes, demonios y curanderos del norte del Perú. Edited by L. Millones \& M. Lemlij. Australis S.A., Lima.

Sharon, D. 2000. Shamanismo y el Cacto Sagrado - Shamanism and the Sacred Cactus. San Diego Museum Papers 37. San Diego, California.

Sharon, D. \& R.W. Bussmann. 2006. Plantas Medicinales en la Obra del Obispo Don Baltasar Jaime Martínez Compañon (Siglo XVIII). Pp. 147-165 in Desde el exterior, El Perú y sus estudios. Edited by L. Millones \& T. Kato Tercer Congreso Internacional de Peruanistas, Nagoya, Universidad Nacional Mayor de San Marcos, Departamento de Publicaciones, Lima.

Sparre, G. \& B. Harling. 1978-2009. Flora of Ecuador (various authors). Council for Nordic Publications in Botany. Botanical Museum, Copenhagen, Denmark.

Stowers, A.W., L. Chen, Y. Zhang, M.C. Kennedy, L. Zou, L. Lambert, T.J. Rice, D.C. Kaslow, A. Saul, C.A. Long,
H. Meade \& L.H. Miller. 2002. A recombinant vaccine expressed in the milk of transgenic mice protects Aotus monkeys from a lethal challenge with Plasmodium falciparum. Proceedings of the National Academy of Science 99(1):339-344.

Teklehaymanot, T. \& M. Giday. 2007. Ethnobotanical study of medicinal plants used by people in Zegie Peninsula, Northwestern Ethiopia. Journal of Ethnobiology and Ethnomedicine 3:12.

Ulloa Ulloa, C. \& P.M. Jørgensen. 1993. Arboles y arbustos de los Andes del Ecuador. Aarhus University (AAU) Reports 30:1-263.

World Health Organization. 2002. WHO Traditional Medicine Strategy 2002-2005. World Health Organization, Geneva.

World Health Organization. 2009. World Health Fact Sheet. www.int/mediacentre/factsheets/fs94/en/index. html. 
Appendix 1. Species encountered and used in Northern Peru to treat malaria and fever.

\begin{tabular}{|c|c|c|c|c|c|}
\hline $\begin{array}{l}\text { Scientific name } \\
\text { [Collection \#] }\end{array}$ & $\begin{array}{l}\text { Vernacular } \\
\text { name }\end{array}$ & $\begin{array}{l}\text { Plant part } \\
\text { used }\end{array}$ & Admin. & Preparation & Use \\
\hline \multicolumn{6}{|l|}{ Asteraceae } \\
\hline $\begin{array}{l}\text { Senecio pseudotites } \\
\text { Griseb. [GER217] }\end{array}$ & Arnica & $\begin{array}{l}\text { Leaves and } \\
\text { Stems, fresh }\end{array}$ & Topical & $\begin{array}{l}\text { In } 1 / 2 \mathrm{~L} \text { water boil } 100 \mathrm{~g} \text { of Arnica for } 10 \\
\text { minutes. Wet a piece of cloth in the warm } \\
\text { tizana, then squeeze a bit of the water } \\
\text { out and place cloth on affected area for } \\
\text { a few seconds. Repeat over and over } \\
\text { again until body temperature is lowered. } \\
\text { Alternatively: Crush } 200 \mathrm{~g} \text { add } 8 \text { drops of } \\
\text { alcohol, warm-up on a pot over the fire. } \\
\text { Place emplasto mixture on top of the } \\
\text { affected area, then cover with a piece of } \\
\text { cloth and then with a piece of plastic. } 2 \\
\text { times a week as needed. }\end{array}$ & $\begin{array}{l}\text { High } \\
\text { fever }\end{array}$ \\
\hline $\begin{array}{l}\text { Tessaria integrifolia } \\
\text { Ruiz \& Pav. } \\
\text { [JULS71, GER12] }\end{array}$ & Pajaro Bobo & $\begin{array}{l}\text { Flowers and } \\
\text { Leaves, fresh }\end{array}$ & Oral & $\begin{array}{l}\text { Boil } 10 \mathrm{~g} \text { Pajaro Bobo per } 1 \mathrm{~L} \text { water. } \\
\text { Combine with Cola de Caballo, Verbena, } \\
\text { Chacur, Paja Blanca, and Espiga de } \\
\text { Maiz. Drink 3-4 times per day for } 15 \\
\text { days. Patient should drink hot solution for } \\
\text { most ailments, and cold solution for bad } \\
\text { breath. }\end{array}$ & Fever \\
\hline \multirow[t]{2}{*}{$\begin{array}{l}\text { Wedelia latifolia } \\
\text { DC. [JULS80] }\end{array}$} & \multirow[t]{2}{*}{ Cuchalman } & \multirow[t]{2}{*}{$\begin{array}{l}\text { Whole plant, } \\
\text { fresh }\end{array}$} & Topical & $\begin{array}{l}\text { Boil } 10 \mathrm{~g} \text { Chulgan with } 1 \mathrm{~L} \text { water. Patient } \\
\text { should take solution at room temperature, } \\
\text { once. }\end{array}$ & \multirow[t]{2}{*}{ Fever } \\
\hline & & & Oral & $\begin{array}{l}\text { Boil } 1 \text { small bundle of Chulgan with } 2 \mathrm{~L} \\
\text { water. Do not mix with other herbs. Patient } \\
\text { should drink lukewarm solution, once. }\end{array}$ & \\
\hline \multicolumn{6}{|l|}{ Caprifoliaceae } \\
\hline \multirow[t]{3}{*}{$\begin{array}{l}\text { Sambucus peruviana } \\
\text { Kunth [EHCHL140, } \\
\text { RBU/PL291, } \\
\text { VFCHL44, ISA131, } \\
\text { ISA87, JULS246, } \\
\text { EHCHL110] }\end{array}$} & \multirow[t]{3}{*}{$\begin{array}{l}\text { Sauco, } \\
\text { Saucotillo }\end{array}$} & $\begin{array}{l}\text { Leaves, } \\
\text { Flowers and } \\
\text { Stems, fresh } \\
\text { or dried }\end{array}$ & Oral & $\begin{array}{l}5-20 \mathrm{~g} \text { per } 1 \mathrm{~L} \text {, boil for } 1 \mathrm{~min} \text {, as tea, } \\
\text { combine with Llonque. } 3 \text { times per } \\
\text { week, up to } 1 \mathrm{~L} \text { per day if needed, or until } \\
\text { fever passes. Take while cold. Rub with } \\
\text { Llonque. }\end{array}$ & \multirow[t]{2}{*}{$\begin{array}{l}\text { Fever, } \\
\text { Yellow } \\
\text { Fever }\end{array}$} \\
\hline & & Leaves, fresh & \multirow[t]{2}{*}{ Topical } & $\begin{array}{l}\text { Bath. Combine with Nogal, Hierba del } \\
\text { Susto, Manzanilla Blanca with a flask of } \\
\text { Timolina. } 2-4 \text { times per month, not to be } \\
\text { used too much because it is very cold. }\end{array}$ & \\
\hline & & $\begin{array}{l}\text { Flowers and } \\
\text { Leaves, fresh }\end{array}$ & & $\begin{array}{l}\text { Boil } 1 \mathrm{~L} \text { of water, then add } 10 \mathrm{~g} \text { of Sauco. } \\
\text { Add Manzanilla, Hinojo, Coleo, Ajenjo, } \\
\text { Toronjil, Pimpinela and Claveles. Cover } \\
\text { and let it sit for } 2-3 \text { minutes. Patient should } \\
\text { drink warm solution, 3-4 cups per day for } \\
1 \text { month. }\end{array}$ & Fever \\
\hline \multicolumn{6}{|l|}{ Clusiaceae } \\
\hline $\begin{array}{l}\text { Hypericum aciculare } \\
\text { Kunth. [ISA135, } \\
\text { ISA35, JULS301] }\end{array}$ & $\begin{array}{l}\text { Hierba } \\
\text { de las } \\
\text { Cordilleras, } \\
\text { Lechuguilla, } \\
\text { Hierba de } \\
\text { Iman } \\
\end{array}$ & $\begin{array}{l}\text { Leaves and } \\
\text { Stems, fresh }\end{array}$ & Oral & $\begin{array}{l}3 \text { leaves, chopped and made into extract. } \\
\text { No Mixing! } 1 \text { tablespoon per day, } 8 \text { days. }\end{array}$ & $\begin{array}{l}\text { Fever, } \\
\text { Intestinal } \\
\text { fever }\end{array}$ \\
\hline
\end{tabular}




\section{Bussmann \& Glenn - Cooling the Heat - Traditional remedies for malaria and}

fever in Northern Peru

\begin{tabular}{|c|c|c|c|c|c|}
\hline $\begin{array}{l}\text { Scientific name } \\
\text { [Collection \#] }\end{array}$ & $\begin{array}{l}\text { Vernacular } \\
\text { name }\end{array}$ & $\begin{array}{l}\text { Plant part } \\
\text { used }\end{array}$ & Admin. & Preparation & Use \\
\hline \multicolumn{6}{|l|}{ Convolvulaceae } \\
\hline $\begin{array}{l}\text { Ipomoea pauciflora } \\
\text { M. Martens \& } \\
\text { Galeotti [GER222] }\end{array}$ & Huanarpo & $\begin{array}{l}\text { Whole plant, } \\
\text { fresh }\end{array}$ & Oral & $\begin{array}{l}\text { Put together in a bottle of cañazo } \\
\text { (Yonque) } 20 \mathrm{~g} \text { of the plant material plus } \\
20 \mathrm{~g} \text { of Cascarilla, Diego Lope, Hualtaco. } \\
\text { Let it sit for } 8 \text { days. Drink temperate } 1 \\
\text { small cup once a day or as needed (max } \\
2 \text { days only). }\end{array}$ & Chills \\
\hline \multicolumn{6}{|l|}{ Cyperaceae } \\
\hline $\begin{array}{l}\text { Scirpus californicus } \\
\text { Steud. subsp. tatora } \\
\text { (Kunth) T. Koyama } \\
\text { [JULS111, GER169] }\end{array}$ & $\begin{array}{l}\text { Balsa, } \\
\text { Totora }\end{array}$ & $\begin{array}{l}\text { Whole plant, } \\
\text { dried }\end{array}$ & Oral & $\begin{array}{l}1 / 2 \text { cup of water add } 10 \mathrm{~g} \text { of Totora, } 10 \mathrm{~g} \text { of } \\
\text { Saze and boil for } 3 \text { minutes. Drink cold, } \\
1 / 2 \text { cup a day for } 8 \text { days. }\end{array}$ & Fever \\
\hline \multicolumn{6}{|l|}{ Fabaceae } \\
\hline $\begin{array}{l}\text { Dolichos lablab L. } \\
\text { [GER235] }\end{array}$ & $\begin{array}{l}\text { Frijol } \\
\text { chileno }\end{array}$ & Fruits, fresh & Oral & $\begin{array}{l}\text { Boil for } 10 \text { minutes } 1 / 2 \mathrm{~kg} \text { of the plant } \\
\text { material in } 1 \mathrm{l} \text { of water. Drink it at room } \\
\text { temperature. } 1 / 2 \text { cup } 2 \text { times a day for } 8 \\
\text { days. }\end{array}$ & Fever \\
\hline $\begin{array}{l}\text { Melilotus albus } \\
\text { Medik. [GER223] }\end{array}$ & Alfalfilla & Seeds, dried & Oral & $\begin{array}{l}\text { Boil for } 10 \text { minutes } 100 \mathrm{~g} \text { of the plant } \\
\text { material in } 1 / 2 \mathrm{~L} \text { of water. Drink cold, } 1 / 2 \\
\text { a cup. Once a day for } 8 \text { days. }\end{array}$ & Fever \\
\hline \multicolumn{6}{|l|}{ Gentianaceae } \\
\hline $\begin{array}{l}\text { Gentianella graminea } \\
\text { (Kunth) Fabris } \\
\text { [EHCHL22, RBU/ } \\
\text { PL285, VFCHL8, } \\
\text { JULS148] }\end{array}$ & \begin{tabular}{|l|} 
Sumaran, \\
Chinchimali, \\
Corpushuay
\end{tabular} & $\begin{array}{l}\text { Whole plant, } \\
\text { fresh or dried }\end{array}$ & Oral & $\begin{array}{l}20 \mathrm{~g} \text { per } 1 \mathrm{~L} \text { water. } 1 \mathrm{~L} \text { daily, } 1 \text { week, } \\
\text { best with food, because it has a bitter } \\
\text { taste. Drink cool while the patient is } \\
\text { fasting. Exceeding doseage can lead to } \\
\text { blindness. }\end{array}$ & Fever \\
\hline \multicolumn{6}{|l|}{ Polygonaceae } \\
\hline $\begin{array}{l}\text { Muehlenbeckia } \\
\text { tamnifolia (Kunth) } \\
\text { Meisner [RBU/ } \\
\text { PL309, ISA30] }\end{array}$ & \begin{tabular}{|l|} 
Chumbiauri, \\
Chumbiauria
\end{tabular} & Leaves, fresh & Topical & $\begin{array}{l}\text { Crush and mix with Yonqué. Limpia, } 2 \\
\text { times a day, no more. }\end{array}$ & Fever \\
\hline \multicolumn{6}{|l|}{ Ranunculaceae } \\
\hline $\begin{array}{l}\text { Thalictrum decipiens } \\
\text { B. Boivin [ISA15] }\end{array}$ & $\begin{array}{l}\text { Chontilla } \\
\text { (Chica) }\end{array}$ & $\begin{array}{l}\text { Whole plant, } \\
\text { dried }\end{array}$ & Topical & $\begin{array}{l}\text { Combine with Ajenco, Salva Real, } \\
\text { Lailambo, } 7 \text { Espiritus, and Agua del } \\
\text { Susto, Twice per month or as illness } \\
\text { requires. }\end{array}$ & \begin{tabular}{|l|} 
Fever, \\
Papera \\
in \\
children, \\
Mumps
\end{tabular} \\
\hline \multicolumn{6}{|l|}{ Salicaceae } \\
\hline \multirow[t]{2}{*}{$\begin{array}{l}\text { Salix chilensis } \\
\text { Molina [TRUBH25, } \\
\text { JULS82, GER39] }\end{array}$} & Sauce & Leaves, fresh & Topical & $\begin{array}{l}\text { Smash leaves for juice, apply as enema } \\
\text { once. Do not ingest. Use only when the } \\
\text { patient is very sick. }\end{array}$ & \multirow[t]{2}{*}{$\begin{array}{l}\text { Fever, } \\
\text { Malaria }\end{array}$} \\
\hline & & & Oral & $\begin{array}{l}\text { Boil } 10 \mathrm{~g} \text { of Sauce and } 10 \text { fruits of Capuli } \\
\text { in } 1 \mathrm{~L} \text { of water for } 30 \text { minutes. Drink warm, } \\
1 / 2 \text { small cup every time the patient has } \\
\text { chills. }\end{array}$ & \\
\hline
\end{tabular}




\begin{tabular}{|c|c|c|c|c|c|}
\hline $\begin{array}{l}\text { Scientific name } \\
\text { [Collection \#] }\end{array}$ & $\begin{array}{l}\text { Vernacular } \\
\text { name }\end{array}$ & $\begin{array}{l}\text { Plant part } \\
\text { used }\end{array}$ & Admin. & Preparation & Use \\
\hline \multicolumn{6}{|l|}{ Solinaceae } \\
\hline $\begin{array}{l}\text { Cestrum auriculatum } \\
\text { L'Hér. [JULS166, } \\
\text { RBU/PL281, } \\
\text { EHCHL172, ISA122, } \\
\text { GER174, EHCHL102] }\end{array}$ & $\begin{array}{l}\text { Hierba } \\
\text { Santa, } \\
\text { Agrasejo }\end{array}$ & $\begin{array}{l}\text { Leaves, fresh } \\
\text { or dried }\end{array}$ & Topical & $\begin{array}{l}\text { Children: Boil } 5 \mathrm{~g} \text { per } 1 / 2 \mathrm{~L} \text { water for } 2 \\
\text { minutes. Adults: Boil } 10 \mathrm{~g} \text { per } 1 \mathrm{~L} \text { water for } \\
2 \text { minutes. Add } 7 \text { Espiritus and Yonque. } \\
\text { Do not mix with other plants. Immerse } \\
\text { body in the leaves and bath water or } \\
\text { apply as enema. } 3-4 \text { times per month. }\end{array}$ & Fever \\
\hline $\begin{array}{l}\text { Solanum americanum } \\
\text { Mill. [EHCHL125, } \\
\text { JULS76, EHCHL87, } \\
\text { GER85, GER159] }\end{array}$ & $\begin{array}{l}\text { Hierba Mora, } \\
\text { Hierba del } \\
\text { Susto, Baja } \\
\text { del Espanto, } \\
\text { Semora }\end{array}$ & $\begin{array}{l}\text { Whole plant, } \\
\text { fresh }\end{array}$ & Topical & $\begin{array}{l}\text { Adult: } 1 \mathrm{~L} \text { of water per } 10 \mathrm{~g} \text {. Children: } 1 / 2 \mathrm{~L} \\
\text { of water per } 10 \mathrm{~g} .3 \text { times per day until all } \\
\text { mucus is released. }\end{array}$ & Fever \\
\hline \multicolumn{6}{|l|}{ Tiliaceae } \\
\hline $\begin{array}{l}\text { Tilia platyphyllos } \\
\text { Scop. [JULS257] }\end{array}$ & Tilo & $\begin{array}{l}\text { Flowers and } \\
\text { Leaves, fresh }\end{array}$ & Oral & $\begin{array}{l}\text { Boil } 1 \mathrm{~L} \text { of water, then add } 10 \mathrm{~g} \text { of Sauco. } \\
\text { Add Manzanilla, Hinojo, Coleo, Ajenjo, } \\
\text { Toronjil, Pimpinela and Claveles. Cover } \\
\text { and let it sit for } 2-3 \text { minutes. Patient should } \\
\text { drink warm solution, } 3-4 \text { cups per day for } \\
1 \text { month. }\end{array}$ & Fever \\
\hline \multicolumn{6}{|l|}{ Verbenaceae } \\
\hline $\begin{array}{l}\text { Verbena littoralis } \\
\text { Kunth [RBU/PL369, } \\
\text { JULS77, EHCHL69, } \\
\text { VFCHL28, GER138] }\end{array}$ & $\begin{array}{l}\text { Verbena, } \\
\text { Berbena }\end{array}$ & $\begin{array}{l}\text { Whole plant, } \\
\text { fresh or dried }\end{array}$ & Topical & $\begin{array}{l}\text { Adults: } 10 \mathrm{~g} \text { of Verbena per } 1 \mathrm{~L} \text { of water. } \\
\text { Children: } 10 \mathrm{~g} \text { of Verbena per } 1 / 2 \mathrm{~L} \text { of water. } \\
\text { Apply enema when water is lukewarm. } \\
\text { Once only. Alternatively boil } 10 \mathrm{~g} \text { per } 2 \mathrm{~L} \\
\text { of water for } 30 \text { minutes, combined with } \\
\text { Matico, Malva, Llantén, and Para Para. } \\
3 \text { times per day for } 8 \text { days. }\end{array}$ & Fever \\
\hline
\end{tabular}

